\title{
NOTE
}

\section{Radioreceptor Assay for Cynomolgus Monkey Serum Luteinizing Hormone}

\author{
TAKAShi YOSHIDA ${ }^{1}$, Kinue YOKOTA ${ }^{2}$, FumiaKi $\mathrm{CHO}^{1}$ AND \\ SHIGEO HONJO ${ }^{1}$

\begin{abstract}
Tsukuba Primate Center for Medical Science ${ }^{1}$, The National Institute of Health and ${ }^{2}$ The Corporation for Production and Research of Laboratory
\end{abstract} \\ Primates Yatabe-machi, Tsukuba-gun, Ibaragi-ken 305
}

\begin{abstract}
Serum luteinizing hormone (LH) of cynomolgus monkeys was measured by radioreceptor assay (RRA). The assay system consisted of $100 \mu \mathrm{l}$ of standard or unknown samples, $100 \mu \mathrm{l}$ of a receptor preparation and $100 \mu \mathrm{l}$ of ${ }^{125} \mathrm{I}-\mathrm{LH}$ (LER-960). Dispersed interstitial cells of mature rat testes were suspended in Tris- $\mathrm{HCl}$ buffer containing $\mathrm{MgSO}_{4}(5 \mathrm{mM})$, bovine serum albumin $(0.1 \%)$ and sucrose $(0.3 \mathrm{M})$ and used as the receptor preparation. ${ }^{125} \mathrm{I}-\mathrm{LH}$ was dissolved in the same buffer. The incubation was carried out at $37^{\circ} \mathrm{C}$ for 2 to $3 \mathrm{hr}$. The nonspecific inhibitory effect of sera in the radioreceptor assay system was compensated for by using LH-free diluent prepared by heat treatment of pooled sera. Validation of the assay demonstrated good reliability in terms of accuracy, precision and sensitivity (equivalent to $3.1 \mu \mathrm{g}$ LER-907/ml of serum). Recovery experiments were performed by adding known amounts of cynomolgus pituitary LH to the normal serum and mean recovery and the standard deviation of the mean was $86 \pm 13 \%$. The intra- and inter-assay coefficients of variation were 7 and $9 \%$, respectively. By using this RRA system, cyclic changes in serum LH during the menstrual cycle were determined in three adult female cynomolgus monkeys. These results indicate that this RRA system is useful in measuring serum LH in female cynomolgus monkeys.
\end{abstract}

In studies on human reproduction, nonhuman primates serve as an excellent experimental model. However, it is unfortunate that there are hardly any assay methods for non-human primate luteinizing hormone (LH). The only useful assay system for non-human primate LH has been the heterologus radioimmunoassay (RIA) method of Niswender et al. (1971) that uses anti-ovine LH serum. On account of the limited availability of this system, attempts have been made to develop a sensitive bioassay

Received April 4, 1984 method for determining circulating levels of $\mathrm{LH}$ in non-human primates. One of them is the method of Wicking et al. (1979) which uses testosterone production by testicular Leydig cells of mice in vitro as the index. The radioreceptor assay (RRA) method that was originally devised for measurement of pituitary LH (Catt and Dufao, 1973) is also a powerful candidate, since a RRA method that is useful in determining plasma follicule stimulating hormone (FSH) of the rat was reported by Minegishi et al. (1980). We establish a RRA system for measurement of serum $\mathrm{LH}$ in the cynomolgus monkey 
(Macaca fascicularis), and could demonstrate changes in the serum LH level of females during the menstrual cycle.

\section{Materials and Methods}

\section{Preparation of $L H$ receptor}

Mature male rats of Wistar-Imamichi strain were obtained from the Imamichi Institute for Animal Reproduction, Dejima-mura, Ibaragi-ken, Japan. Immediately after the rats were decapitated, their testes were removed and weighed. All of the following procedures were performed under chilled conditions. The testes were decapsulated and dispersed in a $0.9 \% \mathrm{NaCl}$ solution with stirring on a magnetic stirrer for $30 \mathrm{~min}$ and then the suspension was filtrated through double layers of cheesecloth to remove fragments of seminiferous tubules. The filtrate was centrifuged at $6,000 \mathrm{rpm}$ for $15 \mathrm{~min}$. The precipitate was resuspended in buffer and used as a receptor preparation. One milliliter of the receptor preparation contained cells derived from $1 \mathrm{~g}$ of the original testicular tissue. The buffer consisted of $40 \mathrm{mM}$ Tris- $\mathrm{HCl}(\mathrm{pH} 7.5), 5 \mathrm{mM} \mathrm{MgSO}_{4}, 0.1 \%$ of bovine serum albumin (BSA) and $0.3 \mathrm{M}$ sucrose.

\section{Hormone preparation}

NIAMDD-human LH (One mg of LER-960 has a potency equivalent to $4,620 \mathrm{IU}$ of $\mathrm{LH}$ ) was used as the highly purified LH preparation for radioiodination with ${ }^{125} \mathrm{I}$. A crude preparation of human LH (One mg of LER-907 contains $60 \mathrm{IU}$ of $\mathrm{LH}$ and $20 \mathrm{IU}$ of FSH) and a highly purified human FSH preparation (NIH-FSH-HS1, one mg contains $187 \mathrm{IU}$ of $\mathrm{LH}$ and 4,990 IU of FSH) were used as competitors for the binding of the radioactive hormone. The serum $\mathrm{LH}$ concentration was expressed in terms of LER-907.

\section{Hypophyseal extract}

An adenohypophysis of a mature female cynomolgus monkey ( $29 \mathrm{mg}$ in wet weight) was dehydrated in cold acetone and dried in vacuo. The dried gland $(9.0 \mathrm{mg})$ was homogenized in $0.9 \mathrm{ml}$ of buffer. After centrifugation of the homogenate at $6,000 \mathrm{rpm}$ for $15 \mathrm{~min}$, the supernatant fluid was collected, divided into many aliquots and stored at $-80^{\circ} \mathrm{C}$. It was used as a $\mathrm{LH}$ preparation of the cynomolgus adenohypophsis.

\section{Iodination of $\mathrm{LH}$}

The iodination of NIAMDD-human LH (LER960) with ${ }^{125}$ I was performed by using lactoperoxidase as the catalyst (Ishii and Farner, 1976). Then, radioiodinated hormone $\left({ }^{125} \mathrm{I}-\mathrm{LH}\right)$ was separated from inorganic iodide by columnchromatography on Sephadex G-75. The specific activity of the labeled LH was estimated to be $8 \mathrm{mCi} / \mathrm{mg}$. Dilution of ${ }^{125} \mathrm{I}-\mathrm{LH}$ was done with assay buffer.

\section{Radioreceptor assay system}

The RRA was carried out by the method of Ishii and Adachi (1977). The assay system consisted of $100 \mu \mathrm{l}$ of an unknown or standard sample solution, $100 \mu \mathrm{l}$ of the receptor preparation, and $100 \mu \mathrm{l}$ of a ${ }^{125} \mathrm{I}-\mathrm{LH}$ solution with about $14,000 \mathrm{cpm}$ of radioactivity in a disposable tube. The mixture was then incubated at $37^{\circ} \mathrm{C}$ for 2 to $3 \mathrm{hr}$ with shaking $(120 \mathrm{cycle} / \mathrm{min})$. At the end of incubation, $1.0 \mathrm{ml}$ of chilled buffer was added to each reaction tube, and the tube was centrifuged at $6,000 \mathrm{rpm}$ for $4 \mathrm{~min}$ at $4^{\circ} \mathrm{C}$. The precipitate was washed twice with chilled buffer by repeating resuspension and centrifugation. The final sediment was counted for the radioactivity in an automatic gamma spectrometer (Model PRIAS, Packard Instru. Comp. Inc.).

\section{Preparation of $\mathrm{LH}$-free diluents}

Three types of diluents which were practically LH free were prepared. To prepare the first type, sera were collected from 64 normal female monkeys and each of them was assayed for LH with the RRA method mentioned above. Three of the 64 sera contained undetectable amounts of $\mathrm{LH}$ even at the sample volume of $300 \mu \mathrm{l}$ per tube and they were used as practically $\mathrm{LH}$ free sera. The second type diluents were prepared as follows : a pooled serum collected from a large number of normal female monkeys was used. It was divided into five glass tubes with $5 \mathrm{ml}$ in each, and then four of them were heated in a boilling water bath for 2, 5, 10 and $20 \mathrm{~min}$ respectively, and the remaining one (a control serum) was not heated. Immediately after heating, each serum was chilled and the coagulum was stirred vigorously. After centrifugation of the coagulum at $10,000 \mathrm{rpm}$ for $2 \mathrm{hr}$, a clear supernatant fluid of heat-treated serum (SHTS) was obtained. The last type diluents were prepared as follows: sera were collected separately from pregnant and nonpregnant females and heated in a boiling water bath for $10 \mathrm{~min}$. SHTSs were obtained by the 
same method as mentioned above.

Radioimmunoassay of 3', 5'-monophosphate (cyclic $A M P$ )

The in vitro bioassay was carried out essentially as previously described (Mendelson et al., 1975). Rat Leydig cells $\left(1 \times 10^{6}\right.$ cells $)$ in $490 \mu 1$ of Medium 199 (GIBCO) containing $22 \mu \mathrm{g}$ of 3isobutyl-1-metylxanthine (Sigma) and $10 \mu 1$ of cynomolgus serum sample was incubated, then the concentration of cyclic AMP accumulated in the reaction medium was measured by the RIA.

\section{Experimental animals}

Cynomolgus monkeys captured in South East Asia were used. Mature female monkeys were housed in individual cages under indoor conditions with a room temperature of $25 \pm 2^{\circ} \mathrm{C}$, relative humidity of $60 \pm 5 \%$, light and dark cycle of 14L10D and fresh air changes 10 times per hr. Every day they were fed with $c a 100 \mathrm{~g}$ of commercially-prepared monkey chows, $c a 100 \mathrm{~g}$ of apples and oranges. These animals were estimated to be more than five years old by examining the dental formula. Menstrual bleeding was daily observed and regular menstrual cycles were confirmed all the year round. Blood samples were withdrawn from the femoral vein under anesthesia with Ketamin-HCl. The samples were centrifuged at $3,000 \mathrm{rpm}$ for $15 \mathrm{~min}$. Sera were separated and stored at $-80^{\circ} \mathrm{C}$ until assayed.

For the determination of serum LH concentrations at different days of the normal menstrual cycle, three female monkeys were employed. Blood samples were collected most days at
1500. For 4 days around the expected day of ovulation (Yoshida et al., 1982), blood samples were collected three times a day at 0900,1500 and 2100 .

\section{Statistic analysis}

Relative potency estimates and their 95\% confidence limits were calculated by the method of Bliss (1952) and statistical analyses for lineality and parallelism were performed according to Sakuma (1964). For the determination of the minimum effective dose of the assay, the leastsignificant-difference method was employed.

\section{Results}

Effects of supernatant fluids from heat-treated sera added the RRA system of binding of ${ }^{125} \mathrm{I}-\mathrm{LH}$

This experiment was conducted in order to know the optimal duration of heattreatment for obtaining the LH-free SHTS under an assumption that boiling destroys receptor binding activity of $\mathrm{LH}$ in serum without changing noncompetitive binding affecting activity of it. ${ }^{125} \mathrm{I}-\mathrm{LH}$ in $100 \mu 1$ of buffer, $100 \mu 1$ of the receptor preparation and $100 \mu 1$ of the SHTSs heated for 0 to 20 min were mixed and incubated. In order to determine nonspecific binding, the pituitary extract equivalent to $25 \mu \mathrm{g}$ of LER-907

Table 1. Effects of duration of the heat-treatment $\left(100^{\circ} \mathrm{C}\right)$ of a pooled normal cynomolgus monkey serum added to the reaction mixture on total and nonspecific binding of ${ }^{125} \mathrm{I}-\mathrm{LH}$ to rat Leydig cells in vitro.

\begin{tabular}{|c|c|c|c|c|c|c|c|c|}
\hline $\begin{array}{l}\text { Duration of } \\
\text { heat-treatment } \\
\text { (min) }\end{array}$ & \multicolumn{4}{|c|}{$\begin{array}{c}\text { Total binding } \\
\text { (\%) }\end{array}$} & & \multicolumn{3}{|c|}{$\begin{array}{c}\text { Nonspecific binding } \\
(\%)\end{array}$} \\
\hline $0 \quad$ (Control) & 4.59 & 3.97 & & & & 1.65 & 1.16 & \\
\hline 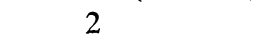 & 6.95 & 7.35 & & & & 1.56 & $1.50-$ & \\
\hline 5 & 7.73 & 8.02 & & * & ** & 1.70 & 1.67 - & n.s. \\
\hline 10 & 8.13 & $8.27-\mathrm{ns}_{\mathrm{s}}$ & n.s. & & & 1.85 & $1.67-$ & \\
\hline 20 & 8.08 & 7.96 n.s. & & & & 1.80 & 1.60 - & \\
\hline
\end{tabular}

Values were obtained from duplicate assays.

n.s. not significant

* $\mathrm{p}<0.05$

$* * \quad \mathrm{p}<0.01$ 
Table 2. Total and nonspecific binding of ${ }^{125} \mathrm{I}-\mathrm{LH}$ to rat Leydig cells in vitro in the presence of the supernatant fluids from heat-treated sera of pregnant and nonpregnant monkeys.

\begin{tabular}{lccc}
\hline Monkeys & $\begin{array}{c}\text { Number of } \\
\text { individuals }\end{array}$ & $\begin{array}{c}\text { Mean total binding } \\
\pm \text { S.D. }\end{array}(\%)$ & $\begin{array}{c}\text { Mean nonspecific } \\
\text { binding } \pm \text { S.D. (\%) }\end{array}$ \\
\hline Nonpregnant & 7 & $7.42 \pm 0.55$ & $1.94 \pm 0.12$ \\
Pregnant & 8 & $8.05 \pm 0.57$ & $1.88 \pm 0.08$ \\
\hline
\end{tabular}

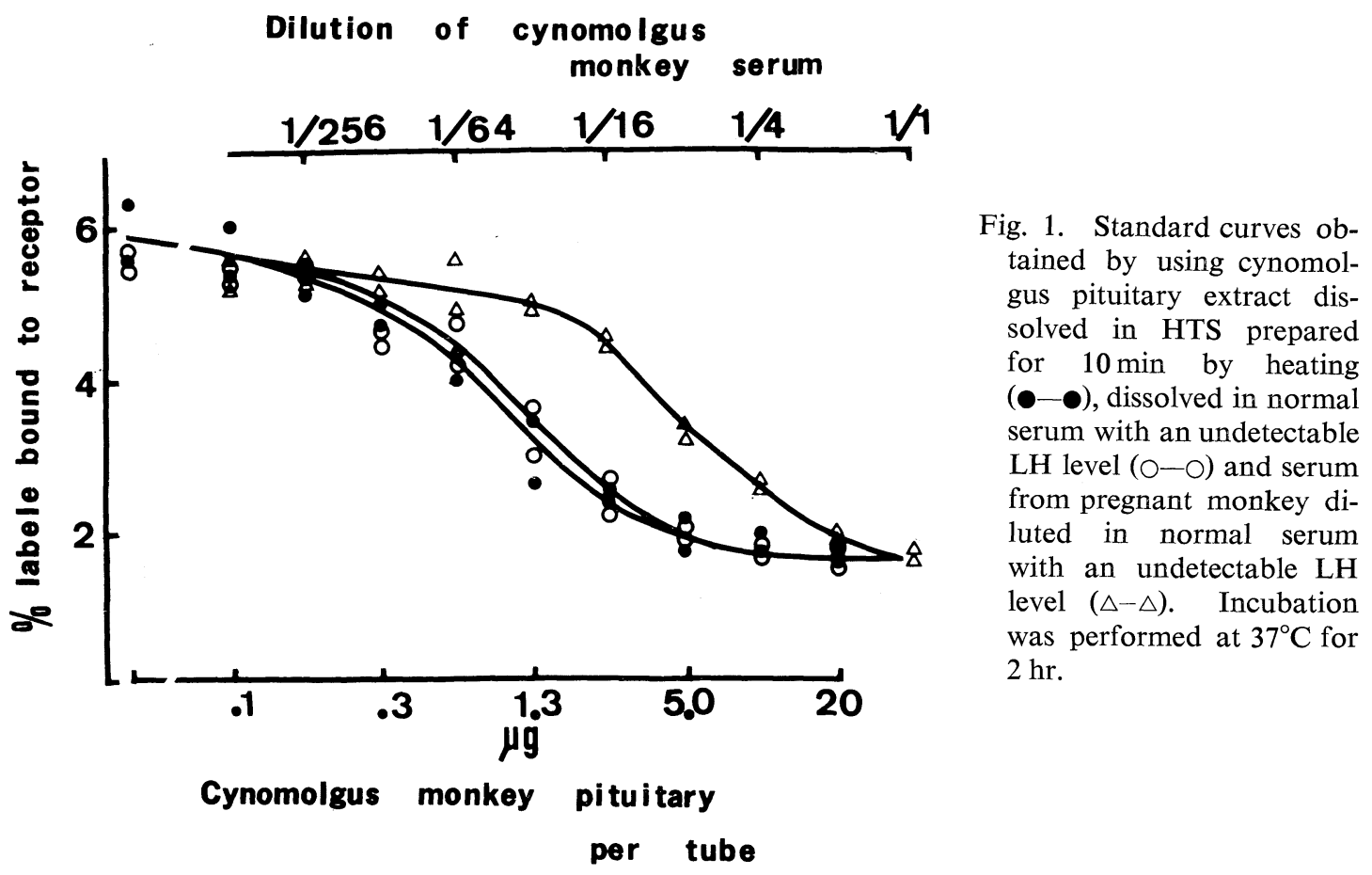

was diluted with corresponding serum and used. As shown in Table 1, the heat-treatment increased the total binding, while it had no significant effect on the nonspecific binding (Table 2). The effect was dependent on the heating duration but reached the maximum at $10 \mathrm{~min}$, showing no more enhancing effects at $20 \mathrm{~min}$.

The effect of the heat-treatment for 10 min was compared between sera of nonpregnant and pregnant (4 to 20 weeks of gestation) cynomolgus (Table 2). Levels of both total and nonspecific binding did not differ significantly $(p>0.05)$ between pregnant and nonpregnant monkeys. The binding levels were also similar to those observed in the sera treated for $10 \mathrm{~min}$ or more in the first experiment.

Comparison of the competition curve between an intact serum containing a large amount of LH and two types of substitute diluents with the pituitary extract

This experiment was designed in order to examine whether the SHTS and sera with an undetectable amount of LH can be used as diluents of the serum and pituitary samples for the LH assay or not. The pituitary 
extract was diluted serially with the SHTS heated for $10 \mathrm{~min}$ of normal serum and one of sera with an undetectable amount of LH. Serum of pregnant cynomolgus monkey ( 3 weeks of gestation) was also diluted serially with the normal serum with an undetectable LH level. They were all used as competitors of the binding of ${ }^{125} \mathrm{I}-\mathrm{LH}$. Three competing curves thus obtained had an approximately common $\mathrm{B}_{0}$ level (binding with no competitor) and also a common nonspecific binding level (Fig. 1). Furthermore, they were approximately parallel with each other. The minimum effective dose of the pituitary, represented as the minimum dose that showed a statistically significant difference $(p<0.01)$ from the $B_{0}$ level by the least-significant-difference method (Sakuma, 1968), was $0.31 \mu \mathrm{g}$. This dose was equivalent to $20 \mathrm{mIU}$. The serum of the pregnant monkey was estimated to contain $\mathrm{LH}$ activity equivalent to a $10.5(7.4-14.7) \mathrm{IU} / \mathrm{ml}$ mean with a $95 \%$ confidence limit of the assay.
Comparison of competitive binding potencies of different primate gonadotropin preparations

Competitive binding potency was compared among the following primate gonadotropin preparations: highly purified human LH (LER-960), a crude human LH preparation (LER-907), highly purified human FSH (NIH-FSH-HS-1) and acetone-dried cynomolgus monkey pituitaries (Fig. 2). As expected from the purity, LER-960 was most potent and the dose required for 50\% inhibition of the specific binding (total binding minus nonspecific binding) was about $10 \mathrm{ng}$ per tube. LER-907 was 60 times less potent than LER-960. Acetone-dried pituitary powder was as potent as LER-907. NIH-FSH-HS-1 showed slight inhibiting potency at dose levels over $0.156 \mu \mathrm{g}$ per tube.

Intra- and inter-assay coefficient of variation and recovery

The mean inter- and intra-assay varia-

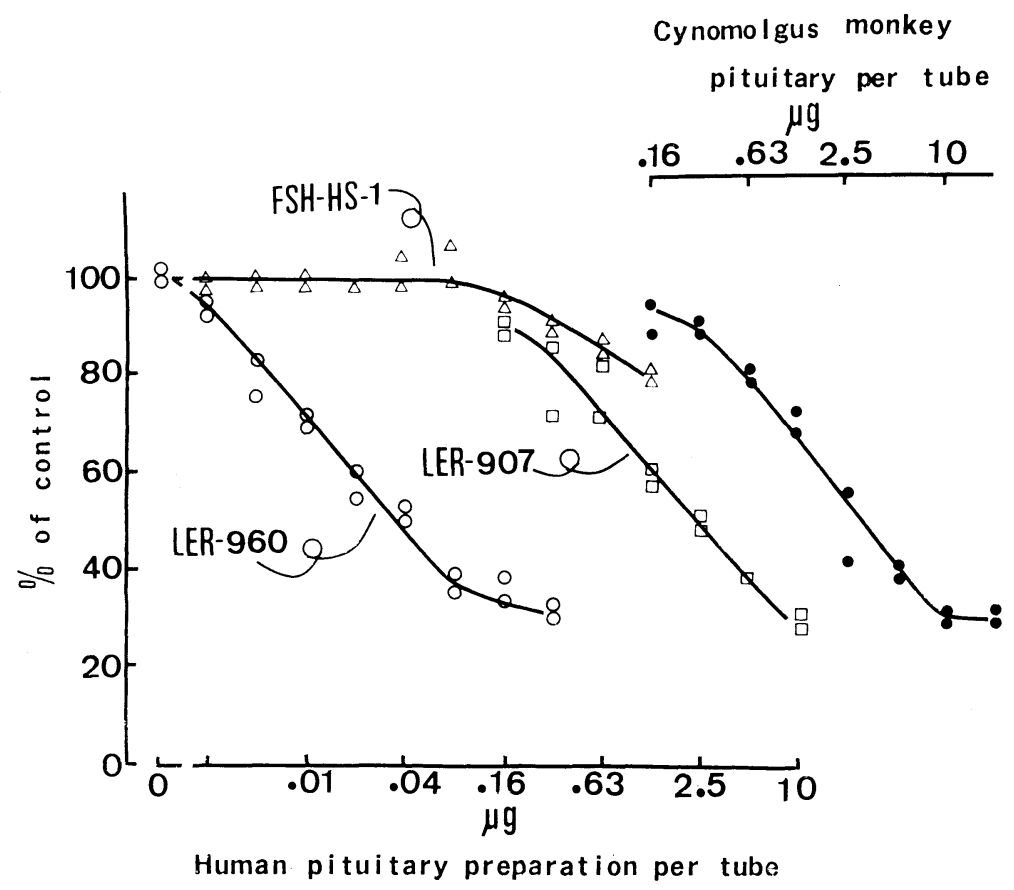

Fig. 2. Comparison of doseresponse curve between cynomolgus pituitary ex-

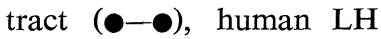
preparation, LER-907 ( $\square-\square)$, highly purified human LH preparation, LER-960 (O-O) and highly purified human FSH preparation, NIH-FSH-HS$1(\Delta-\Delta)$ in LH-RRA. RRA was carried out on system consisting of standard or sample solution $(100 \mu l)$, receptor preparation $(100$ $\mu 1)$ and ${ }^{125}$ I-LH $(100 \mu 1)$. Incubation was performed at $37^{\circ} \mathrm{C}$ for $3 \mathrm{hr}$. 
Table 3. Accuracy test on recovery of LH to normal serum from a female cynomolgus monkey.

\begin{tabular}{ccc}
\hline \hline $\begin{array}{c}\text { LH added } \\
\left(\mu \mathrm{g}^{* *}\right)\end{array}$ & $\begin{array}{c}\text { LH measured* } \\
\left(\mu \mathrm{g}^{* *}\right)\end{array}$ & $\begin{array}{c}\text { Recovery* } \\
(\%)\end{array}$ \\
\hline 0 & $0.46 \pm 0.11$ & - \\
0.5 & $0.85 \pm 0.11$ & $89 \pm 11$ \\
1.0 & $1.23 \pm 0.20$ & $84 \pm 14$ \\
2.0 & $2.08 \pm 0.31$ & $85 \pm 14$ \\
\hline Mean & & $86 \pm 13$ \\
\hline
\end{tabular}

* Mean \pm S.D.

** LH activity is expressed as LER-907 equivalent.

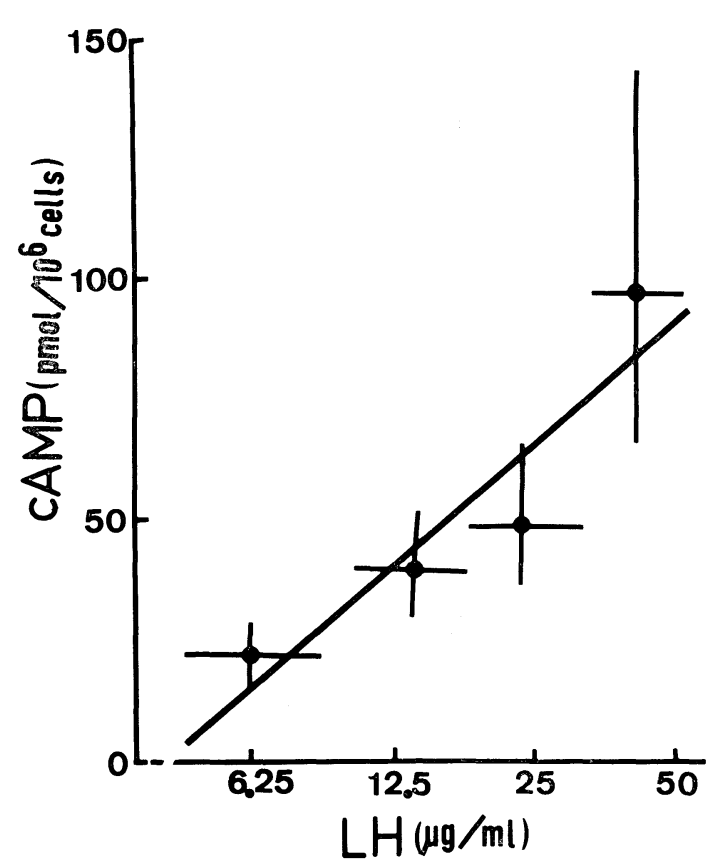

Fig. 3. Correlation between serum LH concentration determined by LH-RRA and stimulation of cyclic AMP accumulation in isolated rat Leydig cell. Horizontal and vertical bars indicate $95 \%$ confidence limit of LH-RRA and cyclic AMP-RIA, respectively.

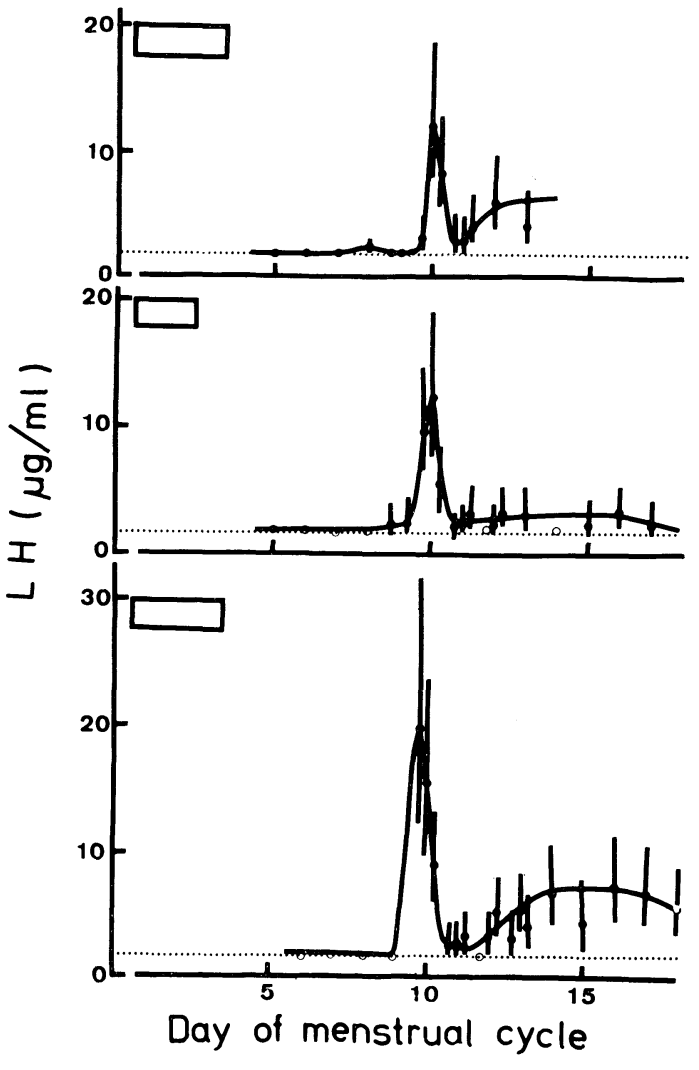

Fig. 4. Typical pattern of serum LH levels during menstrual cycle in the cynomolgus monkey. Vertical bars indicate $95 \%$ confidence limits of the assay. The open bars indicate menses, dotted lines and open circles indicate undetectable levels in RRA and serum containing LH lower than the level, respectively. 
tions estimated from the results of 10 consecutive assays, using 1.25 and $2.5 \mu \mathrm{g}$ of the acetone-dried pituitary powders dissolved in the heat-treated serum as the sample, were 7 and 9 per cent, respectively. The index of precision (lambda) was $0.05 \pm 0.02$ (mean \pm S.D., $n=20$ ). The recovery rate for $\mathrm{LH}$ activity added to the normal serum in the present assay system was studied. When 0.5 to $2.0 \mu \mathrm{g}$ of acetone-dried powder of the cynomolgus monkey hypophysis was assayed as the LH sample added to the normal female serum, the recovery rate ranged from 84 to $89 \%$, and the mean was $85 \%$ (Table 3 ). The standard deviation of the recovery data was $13 \%$.

\section{Correlation between $R R A$ and bioassay}

LH activity data for four different sera were compared between the present RRA and the biological assay using the change in the cyclic AMP concentration in isolated rat Leydig cells as the index (Mendelson et al., 1975). As shown in Fig. 3, activities estimated by these methods were well correlated, $r=0.921$, and statistically significant $(\mathrm{p}<0.05)$.

Serum LH levels during a menstrual cycle determined by the RRA

Changes in serum LH levels during a menstrual cycle were studied in three cynomolgus monkeys by the present RRA method (Fig. 4). A conspicuous LH surge was detectable on day 10 of the cycle in all the three individuals. The serum level of $\mathrm{LH}$ at the time of the surge was between 10 and $20 \mu \mathrm{g} / \mathrm{ml}$ in terms of LER-907. Between days 5 and 9 of the cycle, the LH level was as low as the non-detectable level of the system or just on the marginal level. The second inconspicuous surge or a gradual rise in the $\mathrm{LH}$ level was observed from day 12 of the cycle.

\section{Discussion}

The usefulness of the application of gonadal receptors to the in vitro assay of gonadotropin was pointed out by Catt and Dufau in their review (1973). An RRA system for quantification of monkey and human pituitary LH has already been reported (Leidenberger and Reichert, 1972, 1973). However, these studies were carried out with pituitary preparation or purified human chorionic gonadotropin (hCG) as the sample. When we attempted to apply the RRA method to the assay of serum samples, nonspecific interference by the serum was a serious problem. Saxena et al. (1974) reported a RRA system for measuring the serum LH and hCG using bovine corpora lutea as the receptor preparation, but they mentioned nothing about the nonspecific interference by serum. In our preliminary experiments, a potent nonspecific interference with the binding of ${ }^{125} \mathrm{I}-\mathrm{LH}$ to the receptor preparation was demonstrated in the monkey serum, resulting in a flattening of the standard curve. The total binding was about $10 \%$ or more of the radioactivity bound to the receptor without the influence of the serum and reduced to $6 \%$ in the presence of serum with an undetectable LH level (Fig. 1). Minegishi et al. (1980) established another RRA system for measuring rat plasma FSH employing the FSH-free serum as the compensator for plasma sample obtained by an immunoadsorbent column chromatography. They further employed merthiolate to remove the nonspecific interfering effect of plasma. In the present study, we employed a heat-treatment technique in order to eliminate endogenous LH activity. This technique did not affect the nonspecific interfering activity of normal sera in our assay system. Regardless of whether the donor was pregnant or non-pregnant, heated sera showed the same level of nonspecific interference. 
Furthermore, normal serum with an undetectable LH level was quite as useful as the heated sera, since there was no significant difference in the total binding, nonspecific binding levels or slopes in the inhibition curves obtained with all of these sera as diluent of the sample. The competitive inhibition experiment with human LH and FSH preparation clearly show that this system is sensitive to $\mathrm{LH}$ but not to FSH. A slight inhibition with NIH-FSHHS-1 at high dose levels may be due to contamination by a slight amount of $\mathrm{LH}$ in this preparation. The potency ratio of 60 between LER-907 and LER-960 estimated in the present RRA coincided well to the potency ratio of 77 provided by the NIAMDD. The strong correlation $(r=0.921)$ between the results of the RRA and bioassay with the cyclic AMP production also indicates the reliability of the RRA method.

In the accuracy test, although practically the same recovery rate was obtained with three different doses of $\mathrm{LH}$ added, the recovery rate itself $(86 \%)$ was not satisfactory enough (Table 2). An improvement in our assay system in this point is required.

In the last experiment in which serum LH levels of three female cynomolgus monkeys were measured, the time of the LH surge was the 10 th day of the menstrual cycle in all three cases. In cynomolgus monkeys, the present authors estimated from the distribution of the days of the FSH surge that the day of ovulation was approximately between the 11th and 14th days after menstruation (Yoshida et al., 1982). An FSH surge was observed one or two days prior to ovulation, so the LH surge observed on the 10th day of the cycle coincided with the case of the FSH surge. In general, the fluctuating patterns of circulating LH levels during the normal menstrual cycle in the cynomolgus monkey determined by the RRA evidently resemble those obtained in rhesus monkeys and the ring-tailed lumur by the RIA (Yamaji et al., 1973, Hodgen et al.,
1976, Norman et al., 1978), and those obtained in the rhesus monkey by the in vitro bioassay method (Puri et al., 1980). However, the values for serum LH levels in the cynomolgus monkey reported here are about ten times higher than those obtained in the rhesus monkey by the RIA (Niswender et al., 1971). In rhesus monkeys, basal serum LH levels were overestimated by the RIA and peak serum LH levels were underestimated by the RIA as compared to the results obtained by the bioassay (Neill et al., 1977, Dufau et al., 1977). The reason why these differences occurred is not yet clear. The authors suggest the following two possibilities: one is that the rat Leydig cell $\mathrm{LH}$ receptor has a higher affinity with cynomolgus monkey LH than with human LH, and the other is that the cynomolgus monkey has a higher serum LH level than the other monkeys. It would be interesting to examine serum samples of monkeys other than the cynomolgus monkey with the present RRA system.

\section{Acknowledgements}

We thank Dr. S. Raiti and the NIAMDD Hormone Distribution Program, National Pituitary Agency, for kindly supplying human pituitary hormones. We wish to express our thanks to Professor Susumu Ishii, Waseda University, for his guidance, suggestions and for his help in the preparation of this manuscript; and to Professor Katsumi Wakabayashi and Dr. Masa-aki Hattori, Gunma University, for helpful discussion, advice and kind assistance with the in vitro bioassay of LH.

\section{References}

Bliss, C. I. The Statistics of Bioassay. 2nd ed. Academic Press, New York and London, p. 482 (1952).

Catt, K. J. and M. L. Dufau. Receptors for Reproductive Hormones. (edited by W. O'Malley and A. R. Means). Plenum Press, New York, 
p. 379 (1973).

Dufau, M. L., G. D. Hodgen, A. L. Goodman, and K. J. Catt (1977). Bioassay of circulating luteinizing hormone in the rhesus monkey: comparison with radioimmunoassay during physiological changes. Endocrinology 100, 15571565.

Hodgen, G. D., J. W. Wilks, J. L. Vaitukaitis, H.-C. Chen, H. Papkoff and G. T. Ross (1976). A new radioimmunoassay for follicule-stimulating hormone in macaques: ovulatory menstrual cycles. Endocrinology 99, 137-145.

Ishii, S. and S. Farner (1976). Binding of folliculestimulating hormone by homogenates of testes of photostimulated white-crowned sparrows. Zonotrichia leucophrys gambelii. Gen. Comp. Endocrinol. 30, 443-450.

Ishii, S. and T. Adachi (1977). Binding of avian testicular homogenate with rat follicule stimulating hormone and inhibition of the binding by hypophysial extracts of lower vertebrates. Gen. Comp. Endocrinol. 31, 287-294.

Leidenberger, F. and L. E. Reichert, Jr. (1972). Evaluation of a rat testis homogenate radioligand receptor assay for human pituitary LH. Endocrinology 91, 901-909.

Leidenberger, F. and L. E. Reichert, Jr. (1973). Species differences in luteinizing hormone as inferred from slope variations in a radioligand receptor assay. Endocrinology 92, 646-649.

Mendelson, C., M. L. Dufau and K. J. Catt (1975). Gonadotropin binding and stimulation of cAMP and testosterone production in isolated Leydig cells. J. Biol. Chem. 250, 8818-8823.

Minegishi, T., M. Igarashi and K. Wakabayashi (1980). Measurement of rat serum FSH by radioreceptor assay and comparison with radioimmunoassay. Endocrinol. Japon. 27, 717-725.

Neill, J. D., R. A. Dailey, R. C. Tsou and L. E. Reichert, Jr. (1977). IImmunoreactive LH-like substances in serum of hypophysectomized and prepubertal monkeys: inactive in an in vitro LH bioassay. Endocrinology 100, 856-861.

Niswender, G. D., S. E. Monroe, W. D. Peckham, A. R. Midgley, Jr., E. Knobil and L. E. Reichert, Jr. (1971). Radioimmunoassay for rhesus monkey luteinizing hormone (LH) with antiovine LH serum and ovine LH- ${ }^{131}$ I. Endocrinology 88, 1327-1331.

Norman, R. L., H. Brandt and R. N. Van Horn (1978). Radioimmunoassay for luteinizing hormone (LH) in the ring-tailed lemur (Lemur catta) with anti-ovine $\mathrm{LH}$ and ovine ${ }^{125} \mathrm{I}-\mathrm{LH}$. Biol. Reprod. 19, 1119-1124.

Puri, C. P., V. Puri and T. C. Anand Kumar (1980). Bioactive luteinizing hormone in the plasma and cerebrospinal fluid of female rhesus monkeys. J. Med. Primatol. 9, 39-49.

Sakuma, A. Bioassay-Design and Analysis. 1st ed. Univ. of Tokyo Press, Tokyo, p. 191 (1964). (Text in Japanese).

Saxena, B. B., S. H. Hasan, F. Haour and M. Schmidt-Gollwiter (1974). Radioreceptor assay of human chorionic gonadotropin: detection of early pregnancy. Science 184, 793-795.

Wickings, E. J., M. H. Qazi and E. Nieschlag (1979). Determination of biological active LH in the serum of male rhesus monkey (Macaca mulatta). J. Reprod. Fert. 57, 497-504.

Yamaji, T., W. D. Peckham, L. E. Atkinson, D. J. Dierschke and E. Knobil (1973). Radioimmunoassay of rhesus monkey follicule stimulating hormone (RhFSH). Endocrinology 92, 1652-1659.

Yoshida, T., M. Nakajima, A. Hiyaoka, M. T. Suzuki, F. Cho and S. Honjo (1982). Menstrual cycle lengths and estimated time of ovulation in the cynomolgus monkey (Macaca fascicularis). Exp. Animals 31, 165-174. (Text in Japanese with English summary.) 